[BEATRIZ FERREIRA PIRES]

Doutora em Educação pela Unicamp e professora do curso

de Têxtil e Moda da EACH/USP.

beatrizferreirapires@usp.br

\title{
Forget me Knot - dos anéis e de seus materiais
}

\author{
Forget me Knot - about rings \\ and their materials
}

[resumo] A utilização de adornos corporais, locados sobre ou sob a pele, remonta

a tempos imemoriais. Confeccionados por nossos ancestrais mais distantes, tais ornamentos resultavam da junção de conhecimentos pertencentes a várias ordens - materiais e imateriais. Para executá-los, era necessário conhecer os significados simbólicos das matérias-primas que seriam empregadas, bem como das técnicas utilizadas e das formas executadas. 0 presente artigo, que se debruça sobre o anel Forget Me Knot, criado em 2012 pelo artista e designer israelita Sruli Recht, apresenta um dos possíveis caminhos para se refletir sobre a referida peça.

\section{palavras-chave}

\section{anel; pele; proteção imaterial; sagrado.}

[abstract] Using corporal ornaments, on or under the skin, dates back to ancient times. Made by our most distant ancestors, such ornaments are the result of joint knowledge belonging to various orders - material and immaterial. To execute them, they had to know the symbolic meanings of the raw materials and the techniques to be used, and the ways to perform them. This article looks closely at the ring Forget Me Knot, created in 2012 by the Israeli artist and designer Sruli Recht, and presents one of the possible ways to reflect about this piece.

[keywords] ring; skin; immaterial protection; sacred. 
Introdução

Cada ser histórico traz em si grande parte da humanidade anterior à História. (ELIADE, 1991, p. 9)

Utilizados desde tempos imemoriais pelos nossos ancestrais mais longinquos (membros das sociedades ágrafas),os adornos corporais podem ser divididos, basicamente, em quatro tipos: os que pigmentam a pele e só existem quando desse contato - pinturas faciais e/ou corporais; os que a ela se sobrepõem - anéis, brincos, colares, braceletes; os que nela são inseridos - tatuagens, implantes; e os que dela resultam como reação a estímulos externos - como no caso das escarificações.

Em tempos remotos, a confecção de tais adornos exigia que seu criador possuisse conhecimentos de várias ordens, tanto materiais como imateriais. Assim, cada um deles resultava de uma complexa forma de cognição envolvendo não apenas habilidades manuais, mas também amplos conhecimentos sobre a técnica de feitura a ser empregada, a matéria-prima a ser utilizada, a parte do corpo a que $o$ adorno seriadestinado, bem como os significados simbólicos resultantes do conjunto escolhido e a vinculação da reunião de todos esses elementos com as diferentes divindades particularmente cultuadas.

Atrelado a todos esses saberes, o engendrar de tais adornos agregava elementos imateriais relacionados, por sua vez, a conhecimentos pertencentes às esferas da magia e do sagrado. Por conseguinte, ao utilizá-los, o individuo podia potencializar suas faculdades inatas, adquirir qualidades advindas das matérias-primas e/ou das formas utilizadas e obter proteção contra possiveis malefícios provenientes dessas esferas.

Para exemplificar, entre todas as sociedades que utilizam adornos para adquirir tais beneficios, podemos citar duas práticas realizadas por povos xamanistas. A primeira se refere aos rituais de passagem para o mundo adulto. Neles, com a finalidade de potencializar suas faculdades inatas, os participantes adquirem marcas complementares sob a forma de tatuagens, piercings ou escarificações que Ihes são designadas exclusivamente pelos xamãs. Estes, por transitarem entre as diferentes dimensões e se comunicarem com os diferentes seres, sabem "definir com exatidão o desenho que complementará a personalidade de cada um dos integrantes da tribo" (PIRES, 2005, p. 105).

A segunda prática se refere à indumentária do xamã. Composta por roupas, adornos e complementos, ela constitui o microcosmo que lhe permite desempenhar suas funções. Todos os elementos ali dispostos o são por motivos específicos, e estão relacionados tanto à obtenção de habilidades quanto à proteção. Como exemplo, podemos mencionar a utilização, por parte dos xamãs altaicos, de um colar que "possui uma franja de penas de mochos negros e castanhos" (ELIADE, 1998, p. 177). A utilização de tais penas, que acrescentam aos dons inatos do xamã as qualidades inerentes dessas aves, simultaneamente the concede novas capacidades e proteção.

Atualmente, em nossa sociedade,os intentos pretendidos com esse modo de pensar, fazer e utilizar os adornos, pela grande maioria, há muito se perderam. Ainda assim, uma importante exceção se refere aos que, de fato, atuam como adornos de proteção, talismãs, amuletos e relíquias. Estes, além de serem confeccionados conforme os preceitos da crença religiosa a que pertencem, são utilizados por indivíduos que compreendem seus significados.

0 desvincular dos saberes citados para a feitura dos adornos e a atual vinculação de grande parte desses com seu aspecto formal e com a sazonalidade da moda propiciaram uma variedade de produtos tanto no que tange às configurações obtidas 
e aos materiais utilizados como à variedade e à quantidade de unidades feitas. Tal demanda exigiu que as peças, além de serem confeccionadas por profissionais intelectual e tecnicamente aptos à sua feitura (tais como ourives, joalheiros e designers), fossem também produzidas industrialmente em série.

Pensar nas diferenças existentes entre os processos ancestrais e os contemporâneos nos remete a algumas das reflexões desenvolvidas por Giorgio Agamben em relação à arte e ao modo de produção, em 0 homem sem conteúdo(2012), que toma como base a seguinte frase de Platão em 0 banquete:

qualquer que seja a causa capaz de fazer passar algo do não ser

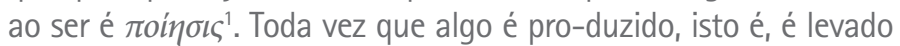

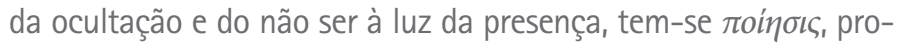
-dução, poesia. (PLATÃO. 0 Banquete, 205b conforme citado por AGAMBEN, 2012, p.104).

Em nota, Agamben esclarece a diferença de significado entre os termos "pro-dução" e "produção", e "pro-duto" e "produto". Pro-dução e pro-duto, diz

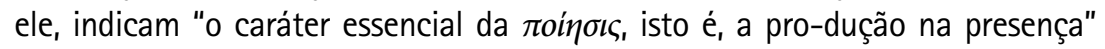
(AGAMBEN, 2012, p. 104). Já os termos produção e produto indicam o fazer da técnica e da indústria.

Pensando sob essa ótica, podemos dizer que os adornos confeccionados por membros das sociedades ágrafasse diferenciam da grande maioria dos atualmente forjados, também e principalmente, pelo fato de que, enquanto aqueles eram/ são pro-dutos, esses - com exceção das peças cuja materialidade final resulta de inquietações e experimentações que as distanciam da joalheria comercial/industrial - são produtos.

Dessa forma, enquanto aqueles adornos de outrora eram pro-duzidos na presença, para cumprir dentro de determinados contextos (tais como os destinados à proteção da sociedade como um todo ou de um indivíduo em particular, dos rituais, das guerras, etc.), um papel que somente eles poderiam desempenhar, esses de hoje, ao preencherem necessidades e lacunas relacionadas quase que exclusivamente à aparência, podem ser feitos em diversos formatos e com diferentes matérias-primas sem que haja nenhuma correspondência simbólica entre a materialidade do objeto eleito e sua representação. Além disso, esses não necessitam que seu executor possua conhecimentos que pertençam a áreas não técnicas.

Adornos desprovidos de poesia e de ancestrais significados, utilizados exclusivamentepara ornamentar, ornar, enfeitar.

\section{Considerações sobre adornos feitas por George Simmel, Aldous Huxley e} Peter Stallybrass

Para o desenvolvimento deste trajeto, acrescentam-se às diferenças dos processos de feitura citados as percepções que a utilização de adornos desperta, seja em quem os porta, seja em quem os observa, segundo as ideias de Simmel, Huxley e Stallybrass. Os três autores elegem como objeto os adornos pertencentes à categoria dos que se sobrepõem à pele e, para denominá-los, utilizam o termo joia (Simmel e Huxley especificam os materiais usados para sua confecção como ouro e pedras preciosas).

0 sociólogo alemão George Simmel publicou, no ano de 1908, o texto denominado Psicologia do adorno, no qual se concentra nos adornos pertencentes à categoria das joias, principalmente os confeccionados com ouro e pedras preciosas. Materiais resistentes e reluzentes, cuja durabilidade e intocabilidade os mantêm "(...) acima da singularidade e acima do destino do seu portador - o que não se verifica de modo algum com a indumentária" (SIMMEL, 2014, p. 71).

Para Simmel, o conceito social de elegância está associado à preservação formal do objeto. Tal preservação só ocorre quando da não contaminação da peça 
pelo corpo, pelo gestual e pelos hábitos do usuário. Sob essa linha de pensamento, o ouro e as pedras, por sua dureza e "fria intocabilidade" (op. cit., p. 71), são as matérias-primas perfeitas para a feitura de adereços.

Nesse sentido, vale acrescentar que é justamente a qualidade de ser perene que nos permite conhecer adornos pertencentes a civilizações antigas, feitos com esses materiais e com outros que possuem a propriedade da durabilidade. Pois é essa qualidade que faz com que os adornos confeccionados com essas matérias-primas, ou com outras que tenham a mesma propriedade, sejam encontrados por expedições arqueológicas em maior número do que as peças de roupas.

Também utilizadas sobre a pele, as vestes, que igualmente alteram e acrescentam cor, textura e forma à silhueta, diferem-se dos adornos principalmente por protegerem o corpo de quem as porta de situações e contingências materiais como, por exemplo, as relacionadas ao clima. Partindo dessa premissa, podemos dizer que, no que concerne a ocorrências materialmente comprovadas, o adorno, em sua grande maioria, é um objeto totalmente desnecessário.

A qualidade de ser materialmente dispensável e supérfluo permite livremente ao adorno, mais do que às vestes, colocar em destaque algumas das características pessoais que definem aquele que o possui. Conforme Simmel: "0 adorno aumenta ou amplia a impressão da personalidade, porquanto actua, por assim dizer, como uma emanação sua" (SIMMEL, 2014, p. 67).

Segundo o entendimento de Simmel, as "influências sensiveis (...) portadoras de uma fulguração espiritual" (op. cit., p. 69) que os seres humanos emitem ao ambiente são ampliadas quando seus corpos possuem adornos. Tal expansão ocorre em razão da segunda característica acima apontada, pertencente ao ouro e à pedra preciosa: a de serem materiais reluzentes. É por causa dessa característica e do elo que ela possui com o que é espiritual que se faz possivel conectar as ideias de Simmel com as de Huxley.

Aldous Huxley, conhecido principalmente por seu romance Admirável mundo novo (1932), publicou em 1956 - como continuidade das reflexões apresentadas em 1954 no livro Asportasda percepção - a obra Céu e inferno². Ambas trazem suas reflexões sobre as experiências que vivenciou quando do uso da mescalina - substância encontrada no peiote, cacto de origem mexicana utilizado há milênios em rituais sagrados indígenas, sobretudo voltados à expansão da consciência. Entre os relatos do autor, um dos fenômenos que percebeu (e que particularmente interessa a este artigo) foi o brilho que alguns elementos, inanimados ou não, emitiam. Brilho que acrescentava às cores, texturas e formas potência e intensidade distintas das cotidianamente observadas. A magnitude dessas características e a percepção desenvolvida sem a supervisão do ego evocam o que Huxley definiu como: "(...) o Todo está em toda parte (...) o Todo é, na verdade, cada coisa" (HUXLEY, 2015, p. 23).

Para falar sobre joias em Céu e inferno (1956), Huxley lança ao leitor a seguinte pergunta: "0 paraíso sempre é um local de joias. Por que isso?" (op. cit., p. 82).

Como exemplo dessa indagação, o autor menciona o seguinte trecho do Antigo Testamento:

13. Estiveste no Éden, jardim de Deus; de toda a pedra preciosa era a tua cobertura: sardônia, topázio, diamante, turquesa, ônix, jaspe, safira, carbúnculo, esmeralda e ouro; em ti se faziam os teus tambores e os teus pífaros; no dia em que foste criado foram preparados. 14. Tu eras o querubim, ungido para cobrir, e te estabeleci; no monte santo de Deus estavas, no meio das pedras afogueadas andavas. (BÍBLIA, Ezequiel28: 13-14) 
Segundo Huxley, a resposta imediata, que aponta como motivo a raridade das pedras preciosas, nos remete a uma questão que deveria ser feita anteriormente a essa: por que tais pedras ganharam o status de preciosas?

Sua resposta é que tal condição se estabelece em razão do fato de elas serem objetos brilhantes e, como tal, possuidoras de uma das caracteristicas que se apresenta com relevanteao espectador que se encontra sob o efeito da mescalina; pois é ele, o brilho, que evidencia (para quem a ingeriu), pelo sentido da visão, sua alteração perceptiva que compreende deslumbrar o mundo à sua volta, e o espaço e o tempo de forma totalizante e diferenciada. Tal percepção aproxima o indivíduo da compreensão do sagrado.

Se para Simmel a utilização de metal e pedras preciosas é perfeita para a confecção de adornos, para Huxley também o é. Enquanto para o primeiro esses materiais garantem o distanciamento do objeto manufaturado do corpo de seu usuário, para o segundo, eles propiciam a aproximação desse com o "Todo". Conforme Huxley, não é por acaso que, ao longo dos séculos, em diferentes religiões (ocidentais e orientais), inúmeros objetos de culto e adornos pessoais, tanto de sacerdotes como de fiéis, foram e são confeccionados com esses materiais.

No que se refere ao simbolismo da pedra, existem variações quanto à forma em que ela se apresenta, a saber, bruta ou lapidada. Mas, independentemente de sua forma, toda pedra se relaciona com o sagrado. Conforme os escritores franceses Jean Chevalier (também filósofo e teólogo) e Alain Gheerbrant (também explorador e editor), coautores e organizadores do Dicionário de símbolos, de 1982: "As pedras preciosas são o símbolo de uma transmutação do opaco ao translúcido e, em um sentido espiritual, das trevas à luz, da imperfeição à perfeição" (CHEVALIER; GHEERBRANT, 2002, p. 701).

Vale lembrar, nesse sentido, que, em várias culturas e em diferentes períodos históricos, pedras, metais (no caso, ouro) e adornos (no caso, anéis) são elementos imbuídos de grande carga mágica e sagrada e, consequentemente, de inúmeros significados simbólicos. A apropriação da linguagem simbólica pelas referidas esferas ocorre porque os símbolos têm a capacidade de expressar, de forma atemporal, o que extrapola o significado convencional do objeto ao qual se referem. Assim, com o intuito de não nos atermos exclusivamente ao significado manifesto desses objetos, utilizaremos ao longo do texto definições provindas dessa linguagem.

Voltando aos adornos confeccionados com pedras,dentro da literatura de ficção, o russo Nikolai Leskov (1831-1895) escreve o conto chamado Alexandrita, no qual um personagem, o velho Wenzel, trabalha como lapidador de pedras preciosas. Não um lapidador qualquer, mas um que, assim como nossos ancestrais artífices, une conhecimentos de várias ordens - resultando naquilo que afirma Walter Benjamin, citando Paul Valéryemum texto em que escreve sobre esse mesmo conto: "A alma, 0 olho e a mão estão assim inscritos num mesmo contexto. Interagindo, eles definem uma prática. Esta prática deixou de nos ser familiar" (BENJAMIN,2012, p. 239).

No conto, Wenzel se comunicava com as pedras e, por esse motivo, realizava lapidações espetaculares que revelavam a exata forma que elas deveriam ter após o processo de lapidação. Conforme dito anteriormente, tal forma só se mostra ou se dá a conhecer quando desvendada no processo de pro-dução.

A pedra, para o vovô Wenzel, não é um ser sem alma, mas animado. Ele sente nela o reflexo da vida misteriosa dos espíritos das montanhas e, peço-Ihe que não ria, estabelece relações misteriosas com eles através das pedras. (LESKOV, 2014, p. 153)

Na narrativa, o poder mágico das pedras se faz presente não somente no fato de elas se comunicarem com o lapidador, mas também na descrição das 
propriedades curativas de várias delas, voltadas não apenas à parte física, como, por exemplo, da safira que alegra o coração, do rubi que multiplica a felicidade, da granada que incinera maus pensamentos etc. (LESKOV, 2014).

Quanto aos metais, o ouro, que "tem o brilho da luz", enquanto para certas culturas é o material com que "a carne dos deuses é feita" (CHEVALIER; GHEERBRANT, 2002, p. 669), é o mais utilizado para a confecção de objetos de culto, bem como também o mais valioso deles. Ainda conforme esses autores:

\begin{abstract}
Entre os Astecas, o ouro é associado à pele nova da terra, no começo da estação das chuvas, antes que ela volte a verdejar. É um símbolo da renovação periódica da natureza. Por esta razão XipeTotec, Nosso Senhor Esfolado, divindade, da chuva, da primavera e da renovação, é igualmente o deus dos ourives. (op. cit., p. 669)
\end{abstract}

Pertencente à civilização mexicana, a cerimônia sagradaTlacaxipehualiztli (que significa "o esfolamento do cadáver") era realizada para o deus Xipe Totec. Durante o ritual, a vítima sacrifical era esfolada e sua pele, utilizada como vestimenta sacerdotal. 0 intuito de tal ato era possibilitar ao sacerdote a realização de determinadas ações rituais que ele só podia executar estando vestido com a pele de outro - sendo essa pele esfolada da vitima "tingida de amarelo como a folha de ouro" (op. cit., p. 669).

Invólucro primeiro do corpo, a pele da vítima sacrifical se torna envoltório sobreposto ao invólucro primeiro do sacerdote.

Como invólucro, a pele carrega consigo todo o histórico do corpo. Por ser o órgão limite, nela estão impressas todas as experiências vividas, tanto as que transitam do interior para o exterior do corpo, como as que fazem esse percurso no sentido contrário. É, justamente, o registro dessas experiências que, ao ser sobreposto e envolver outro corpo, faz com que o indivíduo que a porte se transmute, temporariamente, em outro ser.

Peter Stallybrass ${ }^{3}$ autor do livro 0 casaco de Marx (2008), logo no início do capitulo intitulado $A$ vida social das coisas: roupas, memórias, dor nos apresenta sua visão sobre as relações que as roupas e as joias estabelecem com o corpo que as utiliza. Diz ele:

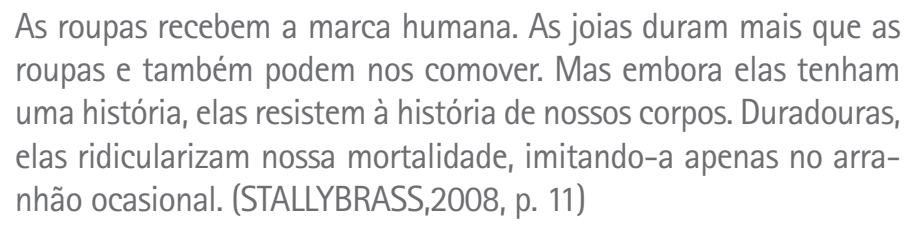

As roupas recebem a marca humana. As joias duram mais que as roupas e também podem nos comover. Mas embora elas tenham uma história, elas resistem à história de nossos corpos. Duradouras, elas ridicularizam nossa mortalidade, imitando-a apenas no arranhão ocasional. (STALLYBRASS,2008, p. 11)

0 interesse de Stallybrass por roupas e joias não passa pela moda e pela sazonalidade desses objetos, mas sim pelos vestígios do corpo que o uso continuado nelas deixou. Para ele, as roupas atuam como registros do gestual habitual do corpo e de suas emanações e, como tal, podem ser vistas como inventários corporais.

Se enquanto têxtil o invólucro absorve caracteristicas humanas, enquanto epidérmico ele as transborda.

Voltando à cerimônia dedicada ao deus Xipe Totec, pintada de amarelo, a pele da vítima sacrifical reluz. Invólucro epidérmico transmudado em metal. Pele metamorfoseada em ouro, invólucro/roupa metamorfoseado em joia.

Como joia, a pele da vítima sacrifical não absorve as experiências vividas pelo sacerdote. Protegido por ela, ele se torna isento dos atos que pratica. Pele joia mantida à parte do íntimo de quem a porta. Pele morta, casulo que enclausura sob sua silhueta o corpo vivo do sacerdote. 
Como se sabe, o ouro é um metal extremamente flexível e maleável que dificilmente sofre oxidação. Normalmente, para que sua resistência aumente, é trabalhado associado à prata, ao cobre, ao zinco, ao níquel ou ao paládio. Cada uma dessas ligas metálicas, formada por dois ou mais metais, fornece ao produto final um coeficiente de deformação plástica e uma coloração diferentes. 0 aquilatamento do ouro é determinado por seu grau de pureza; assim, o ouro 24 quilates é o ouro puro. A não integração material das joias feitas em ouro com 0 corpo humano o faz soberano em sua forma. 0 corpo não as afeta, pelo contrário: dependendo da forma e da dimensão em que são forjadas, são elas que podem afetar o corpo. A não flexibilidade dessas joias se contrapõe à da pele.

Invólucros dispostos sobre pequenas extensões de pele que, imunes ao funcionamento e ao gestual do corpo, não abandonam sua forma inicial. Abrigos contra intempéries de ordem imaterial e, por aproximação, revestimento endurecido, camada rígida, casca, crosta, córtex.

\section{Considerações sobre anéis}

Pertencente ao rol de adornos que são sobrepostos à pele, os anéis (categoria àqual pertence o objeto foco deste artigo) não foram os primeiros adornos corporais confeccionados pelo homem. Os primeiros foram as faixas ou cintos - supostamente trançados de fibras ou pelos - e os pendentes. Alguns exemplares desses últimos datam aproximadamente de 35 mil a 10 mil anos a.C. Conforme Eliana Gola, tais pingentes, "feitos de dentes, de conchas, de ossos e de pedras" (GOLA, 2013, p. 25), podiam possuir configurações naturais, formas de presas e garras ou ainda ser decorados com temas geométricos por meio de incisões.

Ainda segundo Gola (2013), é na Idade do Bronze que o emprego do ouro, da prata e de diferentes pedras para a feitura de adornos diversos é efetivado. $E$ é somente por volta de 2000 a.C., com a utilização de novas técnicas e formas de manipulação, que a prática da ourivesaria se aprimora. Entre essas técnicas, podemos citar a da sondagem por fusão.

Próximo a esse período, no Egito, o ouro era empregado para a feitura de vários adornos, entre eles, os anéis de "sinete" ou "selo". Estes eram assim chamados porque, ao imprimir em argila ou cera símbolos escolhidos por seus proprietários, serviam simultaneamente como assinatura e lacre de documentos e cartas. Utilizados posteriormente na Grécia antiga, nos impérios Romano e Oriental e na Europa da Idade Média, tais anéis, além de evidenciarem o poder (utilizado, por exemplo, por líderes de estado e eminentes comerciantes), atuavam também como sinal de distinção de seus proprietários. Conta-se ainda que o rei Salomão, personagem bíblico, usou seu anel para marcar "todos os demônios que havia reunido para suas obras divinatórias, e eles se tornaram seus escravos" (CHEVALIER; GHEERBRANT, 2002, p. 55).

Embora os significados estabelecidos para esse adorno (que, utilizado nas mãos, envolve parte de um dos dedos) sejam diversos e variem conforme o formato, os materiais de confecção e o dedo no qual é usado, é possivel afirmar que, simbolicamente, todo anel, independentemente da classificação a qualpertença -arqueiro, pescador, luto, comemorativo, etc. - representa um elo, uma conexão, uma vinculação ou uma união que tanto pode ser estabelecida entre seres constituídos de matéria como entre estes e divindades. Ao estabelecer e selar tais vínculos, o anel pode ser visto como um objeto detentor de propriedades mágicas, como atestam ainda Chevalier e Gheerbrant (2002, p. 55): "No plano esotérico, 0 anel possui poderes mágicos. É uma redução do cinto".

Como mencionado antes, diferentemente dos anéis, os cintos estão entre os primeiros adornos confeccionados pelo homem, e apareceram em representações que datam de cerca de 30 mil a 15 mil anos a.C., como é o caso da estatueta de Vênus de Kostenki ${ }^{4}$. Ao se levar em conta as premissas a seguir, se deduz que sua 
confecção/utilização está ligada às esferas da magia e do sagrado e seu uso, a rituais e cultos: primeiro, o período em que esses cintos foram feitos, no qual as dificuldades encontradas para sua concretização perpassavam todas as fases de sua confecção (desde a obtenção e o tratamento dos fios até a feitura do adorno); e segundo, o clima frio das regiões em que foram achados, para o qual a feitura/ utilização de invólucros destinados a cobrir grandes áreas corporais seria muito mais útil. Dessa forma, anel e cinto são elementos que circulam partes do corpo humano e que, ao fazê-lo, atuam como protetores do todo.

Das várias formas com que esse tipo de adornos e apresenta, além do anel de sinete, nos interessa destacar o anel em formato de aliança - termo que vem do latim alligāre, deligāre e significa "1. ligar, atar, prender; 2. unir" (HOUAISS,2012). Nessa forma, o anel evidencia a existência simultânea de posicionamentos e sentimentos que se opõem mutuamente: o de amo-escravo e o de pertencimento-isolamento.

Conforme Chevalier e Gheerbrant, tais posicionamentos e sentimentos podem ser exemplificados na utilização do anel nupcial trocado pelos noivos durante a cerimônia de casamento, "que exige que cada um dos cônjuges se torne, assim, amo e escravo do outro" (CHEVALIER; GHEERBRANT,2002, p. 53). Aqui, 0 anel atua como a representação física do vínculo de pertencimento existente entre o casal e, ao mesmo tempo, de isolamento e distanciamento deste, enquanto célula familiar, do restante da sociedade.

Na mitologia, Prometeu - do latim prudens, de prouidens, o prudente, 0 "pre-vidente" (BRANDÃO, 2009, p. 175) - é obrigado a portar um anel de ferro com engaste de pedra. Ambos, ferro e pedra (não preciosa), foram utilizados para compor o anel como forma de que Prometeu nunca esquecesse o rochedo no qual ficou preso com grilhões de ferro por desafiar os deuses (CHEVALIER; GHEERBRANT,2002, p. 54). Ainda que esse anel não tenha o formato de aliança, seu uso tornava visível não apenas a pena sofrida por Prometeu, mas também sua submissão a Zeus.

Defensor dos homens, Prometeu engana Zeus duas vezes. Na primeira, divide um grande boi em duas porções, uma contendo as carnes e entranhas do bicho, outra contendo somente os ossos, e as apresenta da seguinte forma: a primeira sob o couro do boi, a segunda sob sua gordura branca. Zeus escolheria uma delas, a restante seria entregue aos homens. Zeus escolhe a segunda.

A cólera proveniente do engano causado pela engenhosa artimanha faz com que Zeus prive a humanidade do fogo, "simbolicamente dos nûs, da inteligência, tornando a humanidade anóetos" (BRANDÃO, 2009, p. 175), ou seja, imbecilizada.

Como revanche, Prometeu rouba uma partícula do fogo celeste. A fúria de Zeus mais uma vez se volta contra os homens e também contra o ardiloso estrategista, que é acorrentado com grilhões inextricáveis e submetido à voracidade de uma águia que diariamente lhe devora o fígado. Tudo o que a águia dilacera durante o dia se reconstitui durante a noite. Castigo infindável, só interrompido pela intervenção de Héracles (Hércules) que mata a águia e libera Prometeu.

É interessante notar que o fígado, órgão vital com grande capacidade de regeneração, é simbolicamente associado à cólera, sentimento experimentado por Zeus quando da determinação do castigo. Do latim cholěra, significa "doença proveniente da bile" (HOUAISS, 2012). Zeus impõe a Prometeu um castigo que destroça, justamente, o órgão que gera o sentimento por ele vivenciado no momento que toma consciência das ações que este realizou.

Oculto pela carne e pela pele, tal órgão se mantém alheio ao que ocorre externamente. Desprotegido e posto à vista, pelo rompimento daquelas, expõe Prometeu ao ciclo de vida e morte. 
Pele esfolada do boi que serve como manto e véu que esconde de Zeus alimentos ofertados aos homens. Pele esfolada da vitima sacrifical que oculta a identidade do sacerdote. Pele rasgada de Prometeu que expõe sua coragem esuarecusa de submissão.

\section{Brevíssimas considerações sobre a pele}

Elemento sobre o qual se posicionam os adornos sobrepostos ao corpo e imprescindivel à confecção do anel Forget Me Knot, a pele é o maiorórgão do corpo humano. Invólucro primeiro do ser, énela que o sentido do tato se faz presente, e que a unidade que encerra se relaciona com o todo que a cerca. Rompida, revela o que deveria permanecer oculto, protegido, e expõe o uno a interferências do todo.

Na pele se imprimem reentrâncias, vincos, sulcos, se formam saliências, dobras, pregas. Tecido possuidor de inúmeros desenhos e realizador de incontáveis relevos, que mesmo mutante, serve como elemento identificador jurídico e social do individuo.

Visiveis sobre sua superfície, dispostos de forma não regular, se encontram os demais elementos que com ela formam o tegumento: pelos, cabelos e unhas.

Ininterruptamente renovada e como tal continuamente desprendida do corpo, a pele é responsável por grande parte da poeira existente nos ambientes fechados, construídos, habitados e frequentados pelos humanos.

Vestígios constituídos do ser. Rastros do corpo.

\section{Forget Me Knot}

Forget Me Knot é o nome dado pelo artista e designer israelita, nascido em Jerusalém, que possui cidadanias australiana e islandesa, SruliRecht, a um dos objetos por ele criado - no caso, um anel.

Quando comunicada de forma oral, em razão de a letra k não ser pronunciada na língua inglesa, a frase "forget me knot" pode ser entendida como "forget me not", expressão corriqueira cuja tradução é "não me esqueça".

Knot pode significar nó, laçada, clã, nódulo nos ramos das árvores de onde brotam outros ramos. A utilização desse termo, que na circunstância específica dessa construção é reconhecido somente quando da forma escrita, acrescenta diferentes significados à mesma, todos eles voltados à ideia de vínculo, seja este criado de forma espontânea ou imposta, seja social ou orgânico.

Como vimos anteriormente, também os anéis estão associados à ideia de vinculo. 0 adornoem questão, peça única, feita por Recht em ouro 24 quilates - portanto, ouro puro -, tem sua face externa completamente revestida por um pedaço de pele humana.

Retirada durante uma cirurgia/performance da parte inferior esquerda do abdômen do designer, a tira de pele que serviu de matéria-prima para 0 anel tem as seguintes dimensões: $110 \mathrm{~mm}$ de comprimento por $10 \mathrm{~mm}$ de largura.

0 procedimento que permitiu que a pele de Recht obtivesse a durabilidade necessária para ser utilizada como revestimento do anel em formato de aliança foi a salga - ela foi curtida em uma solução de alúmen, espécie de sulfato que tem propriedades coagulantes. Tal processo, largamente conhecido, já era utilizado por nossos ancestrais para a conservação de couros, peles e carnes de animais abatidos. Em decorrência dele, o tecido epidérmico sofreu alteração na sua cor e ficou mais escuro.

A faixa de pele retirada do abdômen do designer possui alguns fios de outro elemento que compõe o tegumento humano: o pelo. Simbolicamente, os pelos representam a virilidade - do latim virilitas, ätis, "virilidade, força, robustez, valor" (HOUAISS, 2012) - e são associados ao sexo masculino. Os fios que foram mantidos, e que também compõem o adorno,atuam visualmente como uma espécie de identificador do material utilizado. Aliás, conforme descrito no site do autor ${ }^{5}$, para garantir sua autenticidade, o adorno (denominado joia) possui certificado de DNA e é acompanhado por um DVD que mostra o processo completo de sua feitura. 

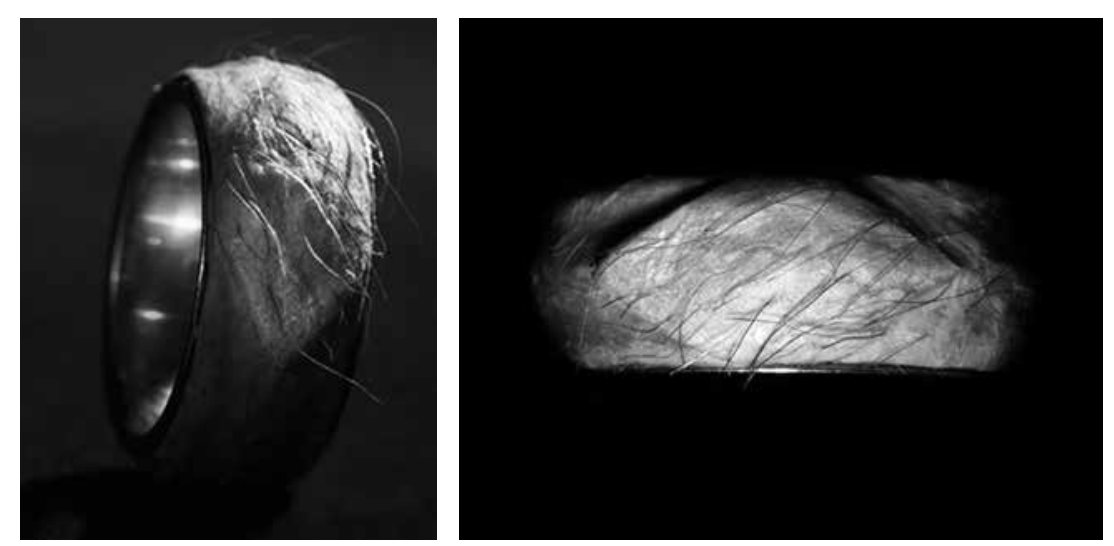

Figuras 1 e 2 - Anel Forget Me Knot, criado por Sruli Recht em 2012.

Fonte:<http://srulirecht.com/forget-me-knot>. Acesso em: 18 jul. 2016.

Recht, que é formado pela universidade australiana Royal Melbourne Instituteof Technology e trabalhou em Londres com o estilista Alexander McQueen, vive atualmente na cidade de Reykjavík (Islândia) e utiliza como uma de suas fontes de inspiração as referências vindas de livros de ficção científica, principalmente os escritos por Bruce Sterling e Philip K. Dick, autor de Androides sonham com oveIhas elétricas?,obra que originou o filme Blade Runner: o caçador de androides(de Ridley Scott). Em seu estúdio/loja, ele desenvolve trabalhos pertencentes às áreas de design de produtos, moda (vestes e acessórios) e arte. Em moda, suas coleções são focadas no público masculino. Voltado a trabalhos conceituais e criador de algumas peças exclusivas, preferencialmente ele utiliza matérias-primas naturais da região em que habita.

Tendência contemporânea que retoma antigos modos de fazer, o emprego de tais matérias-primas não restringe o designer à obviedade de escolha, nem ao uso convencional das mesmas. Para nos atermos aos tegumentos, Recht já confeccionou, por exemplo, vestes com pele de golfinho, tecido de crina de cavalo, seda extraída de uma glândula de aranha. Embora em nossa sociedade a utilização desses materiais não seja comum, nenhum supera em estranhamento o uso da pele humana.

$\mathrm{Na}$ categoria dos adornos, o designer criou uma série de anéis de prata enegrecidos que, com o tempo, pelo contato com a pele do usuário, se tornam prateados. Pele, não mais a que reveste a superfície externa do anel, mas a que o transforma pelo contato.

Ao entender a matéria-prima como algo que engloba não somente os elementos materiais fornecidos pela região, mas também os imateriais, como as lendas e histórias locais, pode-se evocar a lenda islandesa das necropants ou nábrók, que remonta ao século XVII. A materialização dessa lenda está exposta no Museu de Feitiçaria e Bruxaria da Islândia (Galdrasýning á Ströndum), localizado no vilarejo pesqueiro de Hólmavík, situado a 225 quilômetros da cidade de Reykjavík.

Nábróksão calças feitas com a pele, e seus respectivos anexos (pelos e unhas), retirada do corpo de um homem morto. Tal pele, ao ser vestida, assegurava prosperidade financeira a seu usuário.

0 procedimento se dava da seguinte forma: em primeiro lugar, o indivíduo cujo tegumento serviria de matéria-prima para a feitura do respectivo indumento deveria dar sua permissão para que, após ser desenterrado, a parte específica de seu corpo - que compreende a região a partir dos glúteos até os dedos dos pés - fosse esfolada. 0 tegumento deveria se manter intacto ao pro- 
cesso de esfolamento, livre de rasgos e furos. Em segundo lugar, o usufrutuário deveria vestir o traje a partir da perna direita e colocar dentro do saco escrotal deste, juntamente com um papel contendo o símbolo da magia, uma moeda roubada de uma viúva pobre.

Vestidas, as necropants grudavam à pele de quem as portava e com elas se confundiam.

Para que a alma do então proprietário da nábrók se salvasse, este não poderia estar usando-a quando de sua morte. Caso isso acontecesse, sua alma vagaria eternamente pela terra. Desse modo, em vida, ele deveria passar a nábrók para um de seus familiares. 0 novo proprietário deveria vestir a peça de modo a colocar sua perna direita sem que o primeiro proprietário tivesse retirado sua perna esquerda do traje.

Não se sabe se Recht tinha ou não conhecimento dessa lenda quando concebeu 0 anel Forget Me Knot. Sabe-se apenas que, pelo impacto e pelas inúmeras reflexões que o adorno causa, indubitavelmente sua confecção trouxe à luz algo que estava oculto.

\section{Conclusão}

Se voltarmos ao início deste texto, veremos que, por mais intimas que sejam as relações estabelecidas entre os diferentes tipos de adornos corporais e a pele, nenhuma delas cita a confecção de objetos feitos com pedaços de pele pertencentes à própria espécie. A utilização de elementos provenientes de outras espécies animais - pele, pelo, garra, chifre, etc. -, que atualmente acontece de forma corriqueira e se dá principalmente pelo emprego de representações bi ou tridimensionais desses, ocorria originariamente com o uso do elemento que era, verdadeiramente, retirado do corpo do animal. 0 objetivo de usar tal elemento era dotar seu portador das características e habilidades pertencentes ao respectivo animal. Por exemplo, o indivíduo que portava o dente de um leopardo supostamente adquiria a força e a precisão de ação desse animal.

Forget Me Knotpertenceà categoria dos adornos que, simultaneamente, se sobrepõem à pele e dela são feitos. Suporte e matéria-prima oriundos da mesma fonte. Material morto que a ele próprio, vivo, se sobrepõe.

Seguindo o modo de pensar de nossos ancestrais mais longínquos, o possivel comprador e usuário do referido anel adquirirá, junto com o adorno, faculdades de outro ser humano. Considerando que as qualidades humanas são variáveis e várias, e que, em cada indivíduo, se manifestam com intensidades diferentes, seria plausivel pensar que o possível usuário do anel adquiriria todas ou algumas das capacidades - inatas ou adquiridas - de Recht? Ou a ele se somariam repetidas potencialidades pertencentes à espécie?

Outra indagação que se faz pertinente, em razão do tipo de relação que poderá vir a existir entre Recht e o potencial futuro proprietário do adorno, está associada ao significado simbólico que a peça escolhida para ser revestida com parte da pele pertencente a um indivíduo que se encontra vivo - anel em formato de aliança possui: criar vínculos de amo-escravo e/ou de pertencimento-isolamento.

É interessante salientar que a ideia de atar, juntar, unir está presente no próprio nome do adorno.Vínculo forjado em enrijecida pele e puro ouro. A primeira por manipulação, o segundo por vocação. Imaleável adorno que, alheio aos movimentos humanos, se mantém. Que encerra em si elementos provenientes de vários territórios míticos e que evoca em seus observadores sentimentos e sensações que ultrapassam, em muito, os limites da racionalidade, da objetividade ordenada e da temporalidade linear.

Misto de lenda e ficção científica, o anel elaborado por Recht o torna materialmente imortal. Fóssil produzido de si, sua pele não se encontra petrificada por ter permanecido anos enterrada ou imersa em variadas soluções, mas sim por ter sido intencionalmente manipulada. 
Adorno feito não mais com pedra engastada em reluzente aro de metal, mas sim com pele/pedra que a ele envolve e que faz com que o brilho por ele emanado seja sutilmente percebido apenas na espessura que separa as duas peles envolvidas - morta e viva, matéria-prima e suporte.

[Recebido em: 11/04/2016]

[Aprovado em: 21/05/2016]

\section{NOTAS}

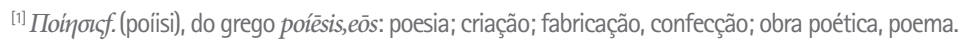

${ }^{[2]}$ As obras As portas da percepção e Céu e inferno foram compiladas e publicadas pela Editora Biblioteca Azul em 2015.

${ }^{[3]}$ Professor de inglês, literatura comparada e teoria literária na Universidade da Pensilvânia.

${ }^{[4]}$ Vênus de Kostenki: peça esculpida em marfim de mamute descoberta em Avdeevo, Kursk (Rússia), em 1967.

${ }^{[5]}$ Disponivel em: <http://www.srulirecht.com/forget-me-knot>. Acesso em: 18 jul. 2016.

\section{REFERÊNCIAS}

AGAMBEN, Giorgio: 0 homem sem conteúdo. Belo Horizonte: Autêntica, 2012, 207 p.

BENJAMIN, Walter: Obras escolhidas I. 8a Ed. São Paulo: Brasiliense, 2012, 271 p.

BÍBLIA. Português. Bíblia Sagrada Católica. Disponivel em: <https://www.bibliaonline.com.br/acf/ez/28>. Acesso em: 18 jul. 2016.

BOUCHER, François. História do vestuário no Ocidente. São Paulo: Cosacnaify, 2010, 480 p.

BRANDÃO, Junito de Souza: Mitologia grega. Vol. I.21ª Ed. Petrópolis: Vozes, 2009, 437 p.

CHEVALIER, Jean; GHEERBRANT, Alain: Dicionário de símbolos. 17ª Ed. Rio de Janeiro: José Olympio, $2002,996 p$.

ELIADE, Mircea. Imagens e símbolos: ensaio sobre o simbolismo mágico-religioso.São Paulo: Martins Fontes, 1991, $178 \mathrm{p}$.

0 xamanismo e as técnicas arcaicas do êxtase. São Paulo: Martins Fontes, 1998, 559 p.

GOLA, Eliana: A joia - história e design. 2ª Ed. São Paulo: SENAC, 2013, 216 p.

HOUAISS, Antônio. Grande dicionário Houaiss de língua portuguesa. Disponível em: <http://houaiss. uol.com.br/>. Acesso em: 18 jul. 2016.

HUXLEY, Aldous: As portas da percepção e Céu e inferno. São Paulo: Biblioteca Azul, 2015, 160 p.

LESKOV, Nikolai: A fraude e outras histórias. São Paulo: Editora 34, 2014, 224 p.

PIRES, Beatriz Ferreira. 0 corpo como suporte da arte: piercing, implante, escarificação, tatuagem.São Paulo: SENAC, 2005, 181 p.

Corpo inciso, vazado, transmudado: inscrições e temporalidades. São Paulo:Annablume/ FAPESP, 2009, $131 \mathrm{p}$.

RECHT, Sruli. Forget Me knot. Disponivel em: <http://srulirecht.com/forget-me-knot $>$. Acesso em: 18 jul. 2016.

SIMMEL, Georg: Filosofia da moda. 2ª Ed. Lisboa: Texto \&t Grafia, 2014, 127 p.

STALLYBRASS, Peter: 0 casaco de Marx. 3a Ed. Belo Horizonte: Autêntica, 2008, 112 p. 